\title{
Chlorate Electrochemical Removal from Aqueous Media Based on a Possible Autocatalytic Mechanism
}

\author{
GABRIELA ELENA BADEA ${ }^{1}$, LOTFI ALEYA ${ }^{2}$, PETRONEL MUSTATEA ${ }^{3}$, DELIA MIRELA TIT ${ }^{4 *}$, LAURA ENDRES ${ }^{4 *}$, SIMONA BUNGAU4, \\ GABRIELA CIOCA \\ 'University of Oradea, Faculty of Sciences, 1 Universitatii Str., 410087, Oradea, Romania \\ ${ }^{2}$ Bourgogne Franche-Comte University, Besancon, France \\ ${ }^{3}$ Carol Davila University of Medicine and Pharmacy, 8 Eroii Sanitari Str., 050474, Bucharest, Romania \\ ${ }^{4}$ University of Oradea, Faculty of Medicine and Pharmacy, 29 N. J iga Str., 410028, Oradea, Romania \\ ${ }^{5}$ Lucian Blaga University of Sibiu, Faculty of Medicine, 10 Victoriei Blvd., 550024, Sibiu, Romania
}

\begin{abstract}
The electrochemical chlorate reduction at the Pt electrode in $0.5 \mathrm{M} \mathrm{H}_{2} \mathrm{SO}_{4}$ deaerated solutions has been studied using potentiostatic steady-state voltammetry. The kinetics parameters (Tafel slope, charge transfer coefficient, current density, and reaction order) were evaluated in function of chlorate concentration (1x10 ${ }^{4}-0.2 \mathrm{M} \mathrm{KClO}$ ). The process of chlorate reduction is a complex one that implies two charge transfer controlled steps with formation of free radicals and an extent potential region controlled by the concentration polarization. The current density dependence of chlorate concentration tends to an exponential growth at concentration $\geq 0.1 \mathrm{M} \mathrm{KClO}$ and becomes exponential in the conditions of the $\mathrm{Cl}_{3}^{-} / \mathrm{Cl}^{-}$catalyst system presence. In the second charge transfer, a surface reaction between free radical $\cdot \mathrm{Cl}^{-}$and platinum electrode with formation of complex anions $\mathrm{PtCl}_{4}{ }^{2-}$ and $\mathrm{PtCl}_{6}{ }^{2-}$ is responsible for the rapid increase of the reaction rate.
\end{abstract}

Keywords: electrochemical reduction, platinum electrode, acid solution

Air, soil, and water pollution are very important issues for environmental protection and ecology, also due to their toxic impact on human bodies [1-3]. Different type of pollutants or wastes [4-7] as heavy metals [8-10], pesticides [11-13], pharmaceutical waste [14], other organic or biological [15-18] contaminants could be incriminated and specific methods for their detection are already optimized and developed, as well as efficient methods for their degradation or removal.

The chlorates are produced at a large scale by the chemical industry and used in a wide varieties of applications. In general, oxyanions of chlorine result into environment from different sources, including the manufacture and use, such as disinfection $[19,20]$, bleaching agents [21], fuel cells [22]. Many recent studies involve the remediation of chlorine species $[23,24]$ as is perchlorate in water. A photoelectrochemical mechanism of chlorate ion reduction was also suggested [25].

Chlorate ions appear as undesirable by-products when chlorine dioxide $\left(\mathrm{ClO}_{2}\right)$ is used for water disinfection. Chlorate dioxide is a highly energetic molecule and becomes a free radical even in diluted aqueous solutions. Chlorate ion is produced through the reaction of residual chlorite $\left(\mathrm{CLO}_{-}^{-}\right)$and free chlorine or hypochlorous acid during secondary disinfection. The overall reactions that describe chlorate formation are as follow:

$$
\begin{aligned}
& \mathrm{ClO}_{2}^{-}+\mathrm{Cl}_{2}+\mathrm{H}_{2} \mathrm{O}=\mathrm{ClO}_{3}^{-}+2 \mathrm{Cl}^{-}+2 \mathrm{H}^{+} \\
& \mathrm{ClO}_{2}^{-}+\mathrm{HOCl}=\mathrm{ClO}_{3}^{-}+\mathrm{Cl}^{-}+\mathrm{H}^{+}
\end{aligned}
$$

Also, chlorine dioxide disproportionate under alkaline condition ( $p H>9$ ) to chlorite and chlorate, according to the following reaction:

$$
2 \mathrm{ClO}_{2}+2 \mathrm{OH}^{-}=\mathrm{ClO}_{2}^{-}+\mathrm{ClO}_{3}^{-}+\mathrm{H}_{2} \mathrm{O}
$$

Chlorate and especially perchlorate ions are considered pollutants for drinking water, being recognized as poisons with a significant risk for health [26-30]. The levels of chlorate may be lowered by reduction to chloride ion, applying biological, chemical, and electrochemical treatment methods.

There are specialized microorganisms that can couple growth to the anaerobic reduction of chlorate or perchlorate to chloride. The processes are based on conversion with microorganisms that use chlorate or perchlorate as electron acceptor and organic compound as electron donor and carbon sources. Numerous investigations on the use of the biological treatment to remove chlorate and perchlorate have been reported in the last twenty years [12, 29-35].

An attractive alternative electron donor may be the hydrogen gas. It has proven its value as a reducing agent in waste water and drinking water treatment [31, 36]. Ferrous salts were reported to remove chlorine disinfection byproducts [37].

It is possible to reduce (per)chlorate to chloride by using the electrochemical treatment, but this method was not studied very much. Researches on perchlorate reduction have used a number of different materials as cathodes, including platinum, tungsten, ruthenium, titanium, aluminum, and carbon doped with chromium (III) oxide or aluminum oxide. However, the method has not been implemented yet in the potable water industry [28].

Different electrodes were used for electrochemical reduction of chlorate ion: a hybrid material, for detection of halogenate ion species in aqueous solutions, modified with: electroactive silver nanoparticles [38], titanium $[24,39]$, carbon [40], boron doped diamond [41], or dimensionally stable anodes for chlorate electrolysis [42]. An autocatalytic chlorate-triiodide reaction was investigated in acid and neutral media [43].

The electrochemical reduction of chlorate becomes a theoretical interest, because its reduction up to chloride ion implies six electrons and therefore more intermediate 
steps. The aim of this work is to establish the kinetics of the electrochemical reduction of chlorate at a platinum electrode in acid medium and to suggest a probable reaction mechanism.

\section{Experimental part}

Material and methods

The experimental studies consisting in the recording of the cathodic polarization curves were performed in a conventional three-compartment electrochemical cell separated by fretted glass disk. The working electrodes, having the geometrical area of $0.06 \mathrm{~cm}^{2}$, were made of polycrystalline platinum. Before the measurements, the electrode was treated, being boiled in 50\% nitric acid solution and washed with double distilled water. A platinum sheet with an area of $1 \mathrm{~cm}^{2}$ was used as counter electrode and a saturated calomel electrode (SCE) - as reference electrode versus which are reported the potentials in the work.

The solutions consisting of $0.5 \mathrm{M} \mathrm{H}_{2} \mathrm{SO}_{4}$ with various concentrations of $\mathrm{KClO}_{3}\left(1 \times 10^{-4}, 1 \times 10^{-3}, 0.01,0.1\right.$, and 0.2 $\mathrm{M})$, were prepared from reagents of Merck purity and double distilled water. Before the measurements, the solutions were non-aerated with purified nitrogen for one hour. All measurements were carried out at room temperature $\left(23 \pm 1^{\circ} \mathrm{C}\right)$.

The polarization curves were recorded using potentiostatic steady-state voltammetry, point by point at 60 s intervals, in the range of potential from +440 to -520 $\mathrm{mV} / \mathrm{SCE}$, using a PS2 potentiostat.

\section{Results and discussions}

The cathodic potentiostatic polarization curves of platinum electrode in $0.5 \mathrm{M} \mathrm{H}_{2} \mathrm{SO}_{4}$ in absence and in presence of various chlorate concentrations are shown in figure 1.

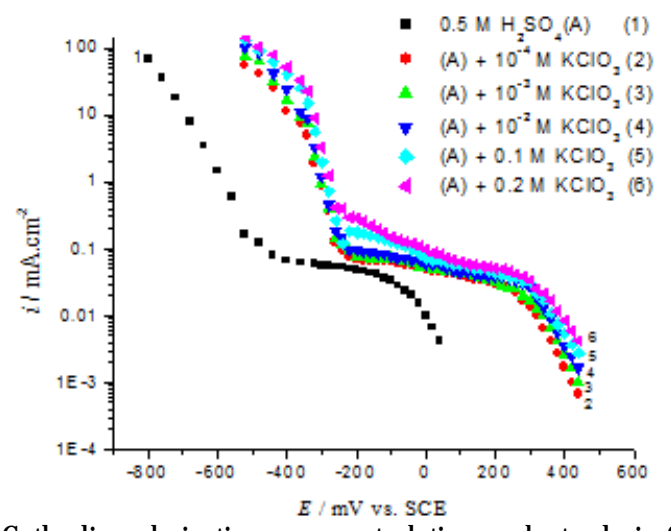

Fig.1. Cathodic polarization curves at platinum electrode in $0.5 \mathrm{M}$ $\mathrm{H}_{2} \mathrm{SO}_{4}$ solutions in absence and in presence of various $\mathrm{KClO}_{3}$ concentrations ( 1 - Aerated solutions; 2-6 - Deaerated solutions)

Curve 1 (fig. 1) corresponds to the main solution containing dissolved oxygen. The processes that take place in this case are the reduction of the dissolved oxygen and of the hydrogen ions. On curve 1 it is observed the oxygen diffusion limiting current, whose value is $41.6 \mu \mathrm{A} / \mathrm{cm}^{2}$. At the potential $<-400 \mathrm{mV} / \mathrm{SCE}$, the current increase is due to the evolution of hydrogen. The hydrogen reaction takes place in the negative potential domain and is not superposed over chlorate reduction. The Tafel slopes of these two electrode processes are shown in figure 2. These values are -108 and $-119 \mathrm{mVxdecade} \mathrm{e}^{-1}$ correspond to oxygen-reduction reaction, respectively to hydrogen evolution.

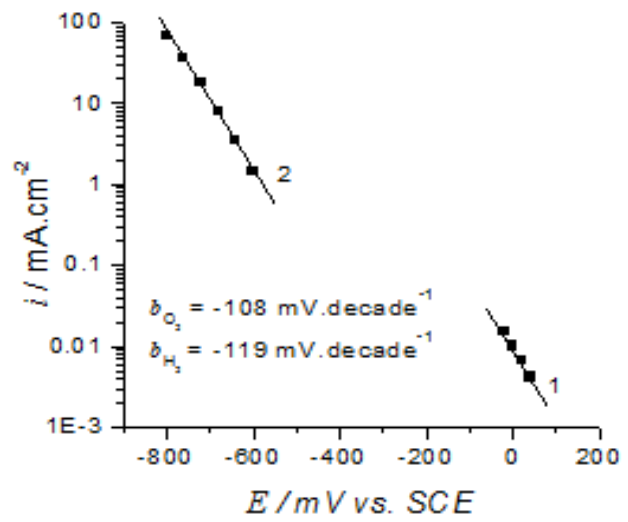

Fig. 2. Tafel lines for the oxygen reduction (1) and hydrogen evolution reactions (2) at Pt electrode in $0.5 \mathrm{M} \mathrm{H}_{2} \mathrm{SO}_{4}$ solution

According to figure 1 , the curves of the chlorate reduction are shifted, showing more positive potential values with increasing chlorate concentration. The polarization curves recorded in presence of chlorate are extended on a potential domain of about $1000 \mathrm{mV}$ and show two charge transfer control regions, separated by an extended limiting current region. The Tafel behavior of the two regions is given in figure $3 a$ and $3 b$, respectively. The Tafel parameters (Tafel slope, $b$ and charge transfer coefficient,a), corresponding to the two Tafel regions - (a) and (b) - are given in table 1.

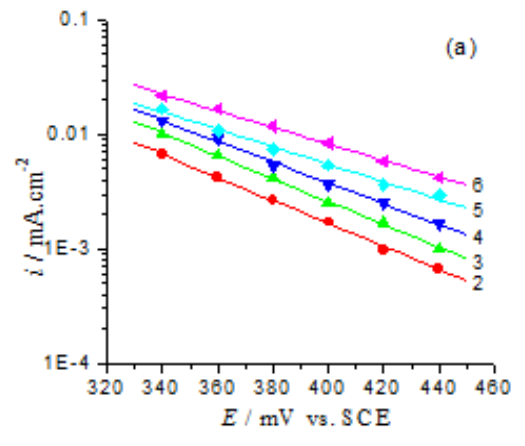

Fig.3. Tafel behavior of the chlorate reduction reaction in $0.5 \mathrm{M} \mathrm{H}_{2} \mathrm{SO}_{4}$ solutions at Pt electrode and various concentrations of $\mathrm{KClO}_{3}$ : 2 - $1 \times 10^{-4} \mathrm{M} ; 3-1 \times 10^{-3} \mathrm{M}$;

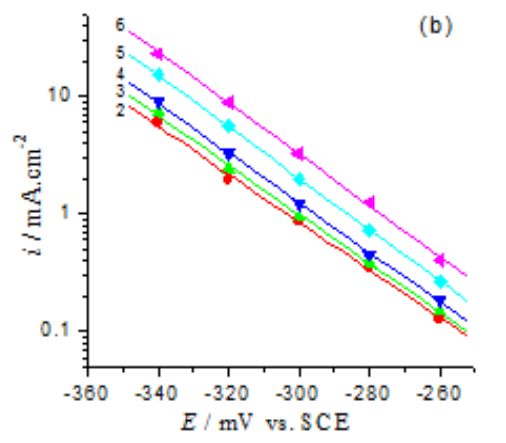
$4-0.01 \mathrm{M} ; 5-0.1 \mathrm{M} ; 6-0.2$ $M,(a)$, (b) -the first and the second step controlled by the charge transfer polarization

Table 1

TAFEL PARAMETERS FOR THE TWO CHARGE TRANSFER CONTROLLED STEPS OF THE CHLORATE REDUCTION AT Pt ELECTRODE IN $0.5 \mathrm{M} \mathrm{H}_{2} \mathrm{SO}_{4}$

\begin{tabular}{|c|c|c|c|c|c|c|}
\hline Step & $\mathrm{KClO}_{3}$ conc. $\rightarrow \downarrow$ Parameters & $1 \times 10^{-4} \mathrm{M}$ & $1 \times 10^{-5} \mathrm{M}$ & $0.01 \mathrm{M}$ & $0.1 \mathrm{M}$ & $0.2 \mathrm{M}$ \\
\hline \multirow{2}{*}{ (a) } & $-b, \mathrm{mV} \cdot$ decade $^{-1}$ & 99 & 100 & 110 & 131 & 137 \\
\hline & $\alpha$ & 0.596 & 0.590 & 0.536 & 0.450 & 0.437 \\
\hline \multirow{2}{*}{ (b) } & $-b, \mathrm{mV} \cdot \mathrm{decade}^{-1}$ & 49 & 48 & 47 & 46 & 46 \\
\hline & $\alpha$ & 1.20 & 1.23 & 1.25 & 1.28 & 1.28 \\
\hline
\end{tabular}


In the potential region (a), the Tafel slope values vary between 99 and $137 \mathrm{mV} /$ decade, which correspond to the theoretical value $(\partial E / \partial \mid n i)=2 R T / F$ for the one-electron charge transfer. The charge transfer coefficient a is close to 0.5 that presumes the absence of the adsorption phenomenon in the reaction kinetics. In the second charge transfer controlled step, the potential region (b), the Tafel slopes have values of $49-46 \mathrm{mV} / \mathrm{dec}$ ade, which corresponds to the catalytic reactions.

The figures $4 \mathrm{a}$ and $4 \mathrm{~b}$ show the relationships between the measured values of $\log i$ and $\log c_{\text {cos }}$ at various constant potentials situated in the two Tafel domains. The reaction order vs. the $\mathrm{CLO}_{3}^{-}$ion $\left(\mathrm{p}_{\mathrm{CIO}-3}\right)$ was calculated according to the relation:

$$
\left(\frac{\partial \log i}{\partial \log c_{\mathrm{ClO}_{3}^{-}}}\right)_{E}=p_{\mathrm{ClO}_{3}^{-}}
$$

The reaction order $(p<1)$ indicates the formation of free radicals in the two charge transfer controlled steps of the chlorate reduction.

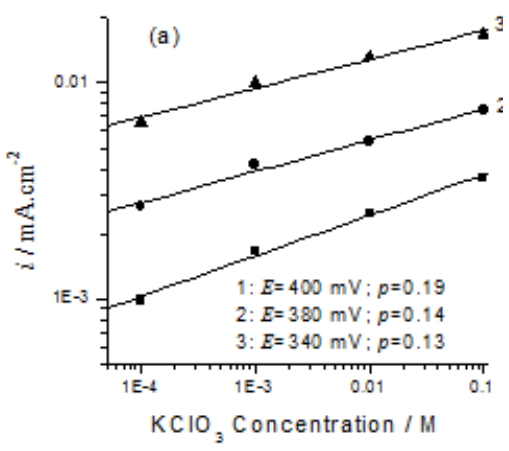

Fig.4. Plots of the cathodic current density vs. chlorate concentration at various constant potentials $(E)$, located in the first charge transfer controlled

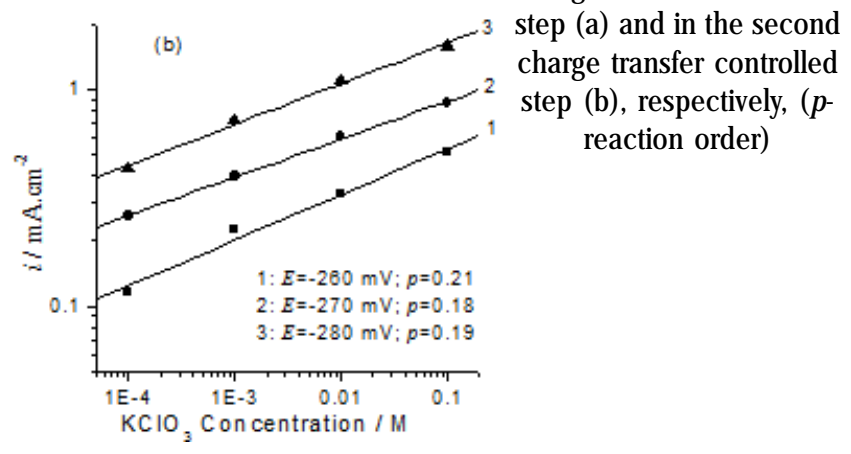

Figures $5 \mathrm{a}$ and $5 \mathrm{~b}$ illustrate the current dependence of chlorate concentration in the case of the various potentials situated in the region of the limiting current. In the figure $5 a$ the current density dependence tends to exponential growth with chlorate concentration (at concentrations $\geq$ $01 \mathrm{M} \mathrm{KClO}_{3}$ ) and becomes exponential in the second part of the limiting current (fig. $5 \mathrm{~b}$ ). This behavior presumes an autocatalytic effect of the chlorate concentration on its reduction.

The redox system $\mathrm{Cl}_{3}^{-} / \mathrm{Cl}^{-}$is a complex one. In the reduction process six electrons are transferred, which presumes several electrochemical steps associated with chemical reactions. In acid media, chlorate may be electrochemically reduced to chlorine or chloride, in accordance with the total reactions $[44,45]$ :

$$
\begin{aligned}
& 2 \mathrm{ClO}_{3}^{-}+12 \mathrm{H}^{+}+10 \mathrm{e}^{-}=\mathrm{Cl}_{2}(\mathrm{~g}) \mathrm{E}^{0}=+1.5 \mathrm{~V} \\
& \mathrm{ClO}_{3}^{-}+6 \mathrm{H}^{+}+6 \mathrm{e}^{-}=\mathrm{Cl}^{-}+3 \mathrm{H}_{2} \mathrm{OE}^{0}=+1.45 \mathrm{~V}
\end{aligned}
$$

The chlorate ion is a strong oxidant and can oxidize $\mathrm{Cl}$ to $\mathrm{Cl}_{2}$ or $\mathrm{Cl}_{3^{\prime}}$, according to the chemical reaction [45]:

$$
\mathrm{ClO}_{3}^{-}+6 \mathrm{H}^{+}+5 \mathrm{Cl}^{-}=3 \mathrm{Cl}_{2}+3 \mathrm{H}_{2} \mathrm{O}
$$
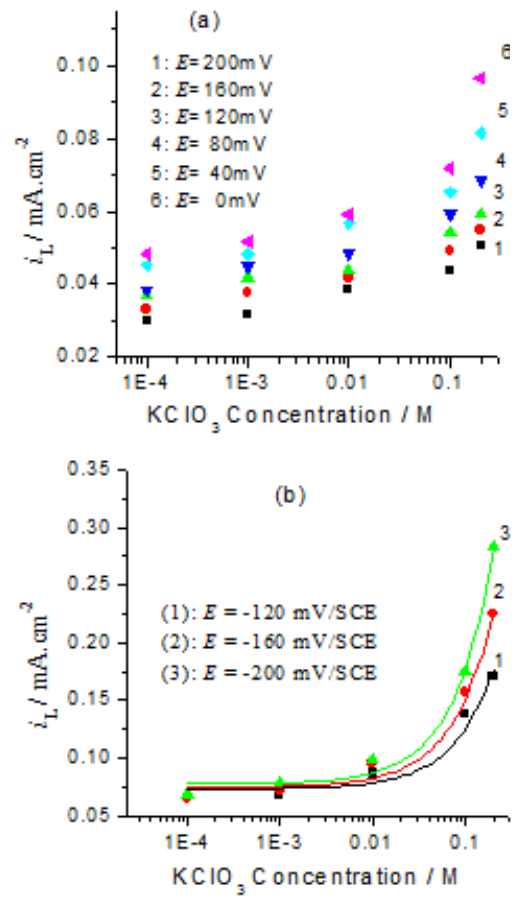

$\mathrm{ClO}_{3}^{-}+6 \mathrm{H}^{+}+8 \mathrm{Cl}^{-}=3 \mathrm{Cl}_{3}^{-}+3 \mathrm{H}_{2} \mathrm{O}$

Also, in solution the following equilibrium appears:

$$
\mathrm{Cl}_{2} \text { (aq) }+\mathrm{Cl}^{-}=\mathrm{Cl}_{3}^{-}
$$

Trichloride ion reduces to chloride ion conform to the reaction:

$$
\mathrm{E}^{0}=+1.415 \mathrm{~V} \quad \mathrm{E}^{0}=+1.415 \mathrm{~V}
$$

In accordance with the potential $p H$ equilibrium diagram [46] for the system chlorine-water, at a temperature of $298 \mathrm{~K}$ in acid medium $(\mathrm{pH}<3.5)$ the chlorate reduction has as reaction product chloride and as intermediate chlorine gas or chlorine (aq). Conform to the activity-pH diagram [46] for chlorine-water system (at $298 \mathrm{~K}, \mathrm{p}_{\mathrm{CI2}}=1$ atm and $\mathrm{pH} \leq 3$ ), the activities of the species $\mathrm{Cl}_{2}(\mathrm{aq})$ and $\mathrm{CL}^{-}$are relevant.

Chlorate reduction can generate free radicals, such as: $\bullet \mathrm{ClO}_{3}, \bullet \mathrm{ClO}_{2}, \bullet \mathrm{ClO}$ or $\bullet \mathrm{Cl}$ [43].

The experimental results showed an extended domain potential for chlorate reduction with various electrochemical behaviors that indicates different mechanisms of the intermediate reactions. According to them, the first charge transfer controlled step implicates the formation of free radicals (the reaction order is subunit conform to figure 4a). The Tafel slopes values (table 1) correspond to some partial reactions with one-electron transfer. These results could be satisfied by the following mechanism:

$$
\begin{aligned}
& \mathrm{ClO}_{3}^{-}+2 \mathrm{H}^{+}+\mathrm{e}^{-} \rightarrow \bullet \mathrm{ClO}_{2}+\mathrm{H}_{2} \mathrm{O} \\
& \bullet \mathrm{ClO}_{2}+\mathrm{H}^{+}+\mathrm{e}^{-} \rightarrow \mathrm{HClO}_{2} \\
& \mathrm{HClO}_{2}+\mathrm{H}^{+}+\mathrm{e}^{-} \rightarrow \bullet \mathrm{OCl}+\mathrm{H}_{2} \mathrm{O} \\
& \bullet \mathrm{OCl}+\mathrm{H}^{+}+\mathrm{e}^{-} \rightarrow \mathrm{HOCl} \\
& \mathrm{HOCl}+\mathrm{H}^{+}+\mathrm{e}^{-} \rightarrow \bullet \mathrm{Cl}+\mathrm{H}_{2} \mathrm{O}
\end{aligned}
$$

$\bullet \mathrm{Cl}+\mathrm{e}^{-} \rightarrow \mathrm{Cl}^{-}$ 
The reactions (11) - (16) imply successive reduction reactions with one-electron transfer and formation of intermediate free radicals. A similar mechanism was indicated by other authors [37] with the difference that the electrons were provided by the oxidation of the ferrous ions to ferric ions. Summing the reactions (11) - (16) the overall reaction is obtained (6). Chlorate reduction in the first potential region has the chloride ion as final product.

In accordance with figure 5a the current density increases slowly with chlorate concentration at small concentrations and tends to the exponential growth at higher concentrations. That presumes an autocatalytic effect of chlorate ions. It must be admitted that at higher concentrations, the chlorate ion interacts with active free radicals $(\bullet \mathrm{ClO})$ conform to reaction:

$$
\text { - } \mathrm{ClO}+\mathrm{ClO}_{3}^{-}+2 \mathrm{H}^{+}+\mathrm{e}^{-} \rightarrow 2 \mathrm{HClO}_{2}
$$

setting up a catalytic loop similar with the free radical $\mathrm{BrO}_{2}$ for bromate reduction [48].

The exponential grow th of the limiting current density with chlorate concentration in the potential region - (100200) $\mathrm{mV} / \mathrm{SCE}$ (fig. 5b) presumes other reactions with catalytic effect. Together with the potential shift to negative direction, the chloride ion concentration increases in the adjacent electrode solution. At higher concentration the chemical reactions (7) and (8) become possible, with generation of trichloride ions, to reduce chlorate to chloride, according to the reaction (10). The system $\mathrm{Cl}_{3} / \mathrm{Cl}^{-}$acts as catalyst similar with the system $\mathrm{I}_{3} / 1$ responsible for the catalytic iodate reduction [49].

In the second charge transfer controlled step, the Tafel slope has low values (table 1), which corresponds to an electrochemical reaction with two-electron transfer. The charge transfer coefficient is $>1$, fact that presumes a surface reaction with catalytic effect. The reaction order is subunit, fact that presumes a radical mechanism. In this potential domain, the chloride concentration near the electrode is sufficiently higher, so that free radical $(\bullet \mathrm{C} 1)$ reacts completely with $\mathrm{Cl}^{-}$and producing the $\cdot \mathrm{Cl}_{2}$ species [39]. The species $\mathrm{Cl}^{-}$and $\left(\cdot \mathrm{Cl}_{2}^{-}\right)$interact with platinum surface, giving complex anions: $\mathrm{PtCl}_{4}^{2-}$ and $\mathrm{PtCl}_{6}^{2-}$ which are reduce to and $\mathrm{Pt}$ surface is regenerated. The corresponding reactions could be:

$$
\begin{aligned}
& 4 \bullet \mathrm{Cl}+4 \mathrm{Cl}^{-} \rightarrow 4 \bullet \mathrm{Cl}_{2}^{-} \\
& \mathrm{Pt}(\mathrm{s})+2 \bullet \mathrm{Cl}_{2}^{-} \rightarrow \mathrm{PtCl}_{4}^{2-} \\
& \mathrm{PtCl}_{4}^{2-}+2 \bullet \mathrm{Cl}_{2}^{-} \rightarrow \mathrm{PtCl}_{6}^{2-}+2 \mathrm{Cl}^{-} \\
& \mathrm{PtCl}_{6}^{2-}+2 \mathrm{e}^{-} \rightarrow \mathrm{PtCl}_{4}^{2-}+2 \mathrm{Cl}^{-} \\
& \mathrm{PtCl}_{4}^{2-}+2 \mathrm{e}^{-} \rightarrow \mathrm{Pt}(\mathrm{s})+4 \mathrm{Cl}^{-}
\end{aligned}
$$

The standard potentials for reactions (21) and (22) are $+0.68 \mathrm{~V}$ and $+0.73 \mathrm{~V}$, respectively.

Summarizing the reactions (18) -(22) it is obtained the overall reaction for this potential region:

$$
4 \cdot \mathrm{Cl}+4 \mathrm{e}^{-} \rightarrow 4 \mathrm{Cl}^{-}
$$

\section{Conclusions}

The electrochemical reduction of the chlorate at Pt electrode in acid medium is a complex process that implies two charge transfer controlled steps with the formation of free radicals and an extended potential region controlled by the concentration polarization. The current density dependence of chlorate concentration tends to an exponential growth at concentration $\geq 0.1 \mathrm{M} \mathrm{KClO}_{3}$ and in the presence of the catalyst system. In the second charge transfer controlled step the chlorate reduction is catalyzed by a surface reaction between Pt electrode and free radicals $\bullet \mathrm{Cl}_{2}$. The final product of chlorate reduction is chloride ion in all potential regions.

\section{References}

1.MOGA, M., PLES, L., BIGIU, N., MANITIU, I., BADEA, M., J. Environ. Prot. Ecol., 12, no. 3A, 2011, p. 1375.

2.TAUS, N., BADEA, M., TAUS, R., SCARnECIU, V., J. Environ. Prot. Ecol., 9, no. 2, 2008, p. 316.

3.TAUS, N., BADEA, M., TAUS, R., PREDIGER, E., J. Environ. Prot. Ecol., 9, no. 4, 2008, p. 773.

4.CIOCA, L.I., MORARU, R.I., Manag. Sustainab. Develop., 2, no. 2, 2012, p. 71.

5.IONESCU, G., RADA E.C., CIOCA, L.I., Environ. Eng. Manag. J., 14, 2015, p. 2537.

6.PRADA, M., POPESCU, D.E., BUNGAU, C., PANCU, R., BUNGAU, C., J. Environ. Prot. Ecol., 18, no. 3, 2017, p. 1146.

7.RADA, E.C., ZATELLI, C., CIOCA, L.I., TORRETTA, V., Sustainability, 10, 2018, p. 257.

8.BADEA, M., MOGA, M., TAUS, N., BIGIU, N., COBZAC, S.C., J. Environ. Prot. Ecol., 10, no. 4, 2009, p. 1006.

9.DAVID, M., BADEA, M., FLORESCU, M., Environ. Eng. Manag. J., 17, no. 2, 2018, p. 317.

10.BALINT, R., NECHIFOR, G., AJMONE-MARSAN, F., Environ. Sci.Processes \& Impacts, 16, no. 2, 2014, p. 211.

11.DA SILVA, D.F., PAIVA, S., FRANCISCO, E., SILVA FERNANDA, G.S., NUNES, G.S., BADEA, M., Pest. Manag. Sci., 71, no. 11, 2015, p. 1497. 12.BADEA, M., IDOMIR, M., TAUS, N., POPESCU, C., SCORTEA, R., COMAN, G., NUNES, G.S., MARTY, J.L., J. Environ. Prot. Ecol., 9, no. 1, 2008, p. 33.

13.GITEA, M.A., BUNGAU, S., GITEA, D., PURZA, L., NEMETH, S., SAMUEL, A.D., BADEA, G., TIT D.M., Rev. Chim.(Bucharest), 69, no. 6, 2018, p. 1303.

14.BUNGAU, S., TIT, D.M., FODOR, K., CIOCA, G., AGOP, M., IOVAN, C., NISTOR CSEPPENTO, D.C., BUMBU, A., BUSTEA, C., Sustainability, 2018, 10, no. 8, p. 2788. doi:10.3390/su10082788

15.NUNES, G.S., LINS, J .A.P., SILVA, F.G.S., ARAUJ O, L.C., SILVA, F.E.P.S., MENDONCA, C.D., BADEA, M., HAYAT, A., MARTY, J.-L., Chemosphere, 111,2014, p. 623.

16.PETREA, N., GINGHINA, R., PRETORIAN, A., PETRE, R., BARSAN, G., OTRISAL, P., MOSTEANU, D.E., Rev. Chim. (Bucharest), 69, no. 7, 2018, p. 1640.

17.ORBECl, C., NECHIFOR, G., STANESCU, R., Environ. Eng. Manag. J., 13, no. 9, 2014, p. 2153.

18.DIACONU, I., GIRDEA, R., CRISTEA, C., NECHIFOR, G., RUSE, E., TOTU, E.E., Rom. Biotech. Lett., 15, no. 6, 2010, p. 5702.

19.SINGER, P.C, O'NEIL, W.K., J. AWWA, 79, 1987, p. 75.

20.GORDON, G., SLOOTMAKERS, B., TACHIYASHIKI, S., WOOD III, D.W, (1990) J. AWWA, 82, 1990, p. 160.

21.ROMANENKO, A.K., LEHTINEN, K., NOTIN, M., Nord Pulp Paper Res. J., 5, no. 2, 1990, p. 83.

22.UNNIKRISHNAN, A., JANARDHANAN, V.M., RAJALAKSHMI, N., DHATHATHREYAN, K.S., J Solid State Electrochem, 22, no. 7, 2018, p. 2107.

23.BROWN, G.M., GU, B. Perchlorate, Springer, Boston, MA, 2006, pp. 17-47.

24.GU, B., BONNESEN, P.V., SLOOP, F.V., BROWN, G.M., Perchlorate, Springer, Boston, MA, 2006, pp. 373-387.

25.OSIEWALA, L., SOCHA, A., PEREK, A., SOCHA, M., RYNCOWSKI, J., J. Water Air Soil Pollut., 224, 2013, p. 1657.

26.CHAUDHURI, S.K., O'CONNOR, S.M., GUSTAVSON, R., ACHERBACH, L.A., COATES, J.D., Appl. Environ. Microbiol., 68, no. 9, 2002, p. 4425. 27.URBANSKY, E.T., Biorem. J, 2, 1998, p. 81.

28.URBANSKY, E.T., SCHOCK, M.R., J. Environ. Manag., 56, 1999, p. 79.

http://www.revistadechimie.ro

REV.CHIM.(Bucharest) $\$$ 70 No. 1 • 2019 
29.BRUCE, R.A., ACHENBACH, I.A., COATES, J.D., Environ. Microbiol., 1, no. 4, 1999, p. 319.

30.COATES, J.D., MICHAELIDOU, U., BRUCE, R.A., O'CONNOR, S.M., CRESPI, J.N., ACHERBACH, L.A., Appl. Environ. Microbiol., 65, no. 12, 1999, p. 5234.

31.KROON, A.G., VAN GINKEL, C.G., J. Environ. Qual., 33, no. 6, 2004, p. 2026.

32.LOGAN, B.E., ZHANG, H., MULVANCY, P., MILNER, M.G., HEAD, I.M., UNZ, R.F., Appl. Environ. Microbiol., 67, no. 6, 2001, p. 2499.

33.0'CONNOR, S.M., COATES, J.D., Appl. Environ. Microbiol., 68, no. 6,2002, p. 3108.

34.THORELL, H.D., STENKLO, K., KARLSSON, I., NILSSON, T., Appl. Environ. Microbiol., 69, no. 9, 2003, p. 5585.

35.WU, J., UNZ, R.F., ZHANG, H., LOGAN, B.E., Biorem. J, 2001, 5, no. 2, p. 119.

36.MILLER, J.P., LOGAN, B.E., Environ. Sci. Technol., 34, no. 14, 2000, p. 3018.

37.KATZ, A., NARKIS, N., Water Res., 35, no. 1, 2001, p. 101. 38.MANIVEL, A., SIVAKUMAR, R., ANANDAN, S., ASHOKKUMAR, M., Electrocatal., 3, 2012, p. 22.
39.GIRENKO, D.V., VeliChenKO, A.B., Surf. Engin. Appl. Electrochem., 54, no. 1, 2018, p. 88.

40.PHOUGAT, N., VASUDEVAN, P., J HA, N.K., BANDHOPADHYAY, D.K., Transition Metal. Chem., 28, no. 7, 2003, p. 838.

41.BRITO, C.N., ARAUJ O, D.M., MARTINEZ-HUITLE, C.A., RODRIGO, M.A., Electrochem. Commun., 55, 2015, p. 34.

42.EVDOKIMOV, S.V., Russian J. Electrochem., 37, no. 4, 2001, p. 363.

43.MOHAMMAD, A.M., AWAD, M.I., TAKEO, O., J. Adv. Res., 1, no. 3, 2010, p. 209.

44.HOLLEMAN, A.F., WIBERG, E., WIBERG, N., Inorganic Chemistry, Academic Press, London, 2001, p. 1761, p. 446.

45.KOLODZIEI, B., HABASHI, F., Can. J. Chem., 63, 1985, p. 935.

46.CHENG, C.Y., KELSALL, G.H.J., Appl. Electrochem., 37, no. 11, 2007, p. 1203

47.ZUO, Z., KATSUMURA, Y., UEDA, K., ISHIGURE, K., J. Chem. Soc. Faraday Trans., 93, no. 4, 1997, p. 533.

48.BADEA, G.E., BADEA, T., Rev. Roum. Chim., 51, no. 2, 2006, p. 127. 49.BADEA, G.E., Rev. Roum. Chim., 52, no. 5, 2007, p. 491.

Manuscript received: 11.09 .2018 